\title{
KECENDERUNGAN MASYARAKAT MEMILIH LEMBAGA PENYELESAIAN SENGKETA EKONOMI SYARIAH
}

\author{
Nurhasanah dan Hotnidah Nasution \\ UIN Syarif Hidayatullah Jakarta \\ Jl. Ir.H. Juanda No. 95, Ciputat, Jakarta Selatan \\ E-mail: nurhasanah@uinjkt.co.id
}

\begin{abstract}
The People's Choice in The Completion of Sharia Economic Dispute. Background research is the fact that lack of syariah economic cases filed and decided by the institution of litigation and non-litigation. This research is exploratory research that uses qualitative approach to explore facts sharia law in an economic context. Data in the form of a questionnaire/questionnaire is processed only to describe the percentage of sharia economic community propensity choose dispute resolution institutions. This description is preliminary data that drove researchers to explore the points required questions in the interview. Mismatch between quantitative data processed by the facts on the ground shows that people choose a wide selection of sharia economy in resolving disputes.
\end{abstract}

Keywords: sharia economic dispute, solution, litigation, non-litigation

\begin{abstract}
Abstrak. Kecenderungan Masyarakat Memilih Lembaga Penyelesaian Sengketa Ekonomi Syariah. Fakta minimnya perkara ekonomi syariah yang diajukan dan diputus oleh lembaga litigasi dan non-litigasi menjadi latar belakang penelitian. Penelitian ini merupakan jenis penelitian eksploratif yang menggunakan pendekatan kualitatif untuk mengunggkap fakta-fakta hukum dalam konteks ekonomi syariah. Data berupa angket/kuesioner diolah hanya untuk mendeskripsikan besaran persentase kecenderungan masyarakat ekonomi syariah memilih lembaga penyelesaian sengketa. Deskripsi ini merupakan data awal yang mengantarkan peneliti untuk menggali poin-poin pertanyaan yang dibutuhkan dalam wawancara. Mismatch antara hasil olahan data kuantitatif dengan fakta di lapangan terlihat bahwa masyarakat memilih beragam pilihan dalam menyelesaikan sengketa ekonomi syariah.
\end{abstract}

Kata Kunci: sengketa ekonomi syariah, solusi, litigasi, non-litigasi

\section{Pendahuluan}

Amanat UU No. 3 Tahun 2006 pasal 49 tentang perubahan UU No. 7 Tahun 1989 tentang Peradilan Agama ${ }^{1}$ yang diamanden terakhir kali dengan UU No. 50 Tahun 2009 memberi arah tentang perluasan kompetensi (yurisdiksi) absolut peradilan agama untuk menyelesaikan sengketa ekonomi syariah ${ }^{2}$. Namun Pada tahun 2008

Naskah diterima: 17 Januari 2016; Direvisi: 8 Juni 2016; Disetujui untuk diterbitkan: 16 Juni 2016.

${ }^{1}$ Pasal 49 UU No. 3 tahun 2006 menjelaskan bahwa pengadilan agama bertugas dan berwenang memeriksa, memutus dan menyelesaikan perkara-perkara di tingkat pertama antara orang-orang yang beragama Islam di bidang perkawinan, waris, wasiat, hibah, wakaf, zakat, infaq, shadaqah, ekonomi syariah. Yang dimaksud dengan ekonomi syariah adalah perbuatan atau kegiatan usaha yang dilaksanakan menurut prinsip syariah, antara lain meliputi bank syariah, lembaga keuangan mikro syariah, asuransi syariah, reksa dana syariah, obligasi syariah dan surat berharga berjangka menengah syariah, sekuritas syariah, pembiayaan syariah, pegadaian syariah, dana pensiun lembaga keuangan syariah, dan bisnis syariah.

2 Undang-undang ini dilatarbelakangi oleh Undang-Undang Nomor 4 Tahun 2004 tentang Kekuasaan Kehakiman sebagai undangundang organik atas pasal 24 Undang-Undang Dasar Tahun 1945 seiring dengan lahirnya UU No. 21 Tahun 2008 tentang Perbankan Syariah ${ }^{3}$, khusus dalam penyelesaian sengketa perbankan syariah tidak lagi absolut menjadi kewenangan peradilan agama hal ini dikarenakan pasal 55 (1) UU No. 21 Tahun 2008 menetapkan penyelesaian sengketa perbankan syariah dilakukan oleh pengadilan dalam lingkunganmperadilan agama; ayat (2), "Dalam hal para pihak telah memperjanjikan penyelesaian sengketa selain sebagaimana dimaksud pada ayat (1), penyelesaian sengketa dilakukan sesuai dengan isi akad. Selanjutnya

\footnotetext{
Pasca Amandemen dengan sistem satu atap (one roof system).

3 Lahirnya Undang-Undang Nomor 21 Tahun 2008 tentang Perbankan Syariah, tidak serta merta dikatakan bahwa UndangUndang Nomor 3 Tahun 2006 tidak berlaku lagi karena dari segi asas hukum di sini tidak boleh diberlakukan asas lex posteuri lex priori (hukum yang lalu tidak berlaku karena adanya hukum yang baru). Undang-Undang Nomor 21 Tahun 2008 dan Undang-Undang Nomor 3 Tahun 2006, memiliki legium hukum yang berbeda. Undang-Undang Nomor 21 Tahun 2008 adalah tentang Perbankan Syariah sedangkan Undang-Undang Nomor 3 Tahun 2006 tentang Peradilan Agama. Oleh karena itu berdasarkan teori hukum, UU No. 21 tahun 2008 tidak dapat mengesampingkan UU No. 3 Tahun 2006.
} 
pada penjelasan Pasal 55 ayat (2) UUPS disebutkan bahwa yang dimaksud dengan penyelesaian sengketa dilakukan sesuai dengan isi akad adalah upaya sebagai berikut: (1) Musyawarah; (2) Mediasi perbankan; (3) Melalui Badan Arbitrase Syariah Nasional (BASYARNAS) atau lembaga arbitrase lain; dan/atau (4) Melalui pengadilan dalam lingkungan peradilan umum.

Ketentuan Pasal 55 ayat (2) beserta penjelasannya itu menunjukkan bahwa telah terjadi reduksi terhadap kompetensi peradilan agama dalam bidang perbankan syariah yang mana dari penjelasan Pasal 55 Ayat (2) UU No. 21 Tahun 2008 tersebut, ternyata peradilan umum diberi kompetensi dalam penyelesaian perkara ekonomi syariah dalam bidang perbankan syariah yang mana para pihak diperbolehkan memilih peradilan umum sebagai choice offorum dalam menyelesaikan sengketa perbankan sehingga hal ini berimplikasi mereduksi kewenangan peradilan agama dalam menyelesaikan sengketa perbankan yang sebagian ahli berpendapat adanya choice of forum ini merupakan inkonsistensi pembentuk undang-undang dalam merumuskan aturan hukum.

Persoalan dualisme penyelesaian sengketa perbankan akhirnya mendorong salah satu nasabah dari PT. Bank Muamalat Indonesia yaitu Dadang Ahmad untuk mengajukan permohonan uji materiil terhadap undang undang perbankan syariah, khususnya pada pasal 55 ayat (2) dan (3) yakni melalui perkara nomor 93/ PUU-X/2012 perihal pengujian UU Nomor 21 tahun 2008 tentang perbankan syariah terhadap UndangUndang Dasar Negara Republik Indonesia.

Produk akhir dari permohonan uji materiil yang diajukan oleh Dadang Ahmad adalah Putusan Mahkamah Konstitusi Nomor 93/pUU-X/2012 yang dalam amar putusanya menyatakan mengabulkan permohonan pemohon untuk sebagian yakni: penjelasan pasal 55 ayat (2) UU No. 21 Tahun 2008 tentang perbankan syariah (Lembaran Negara Republik Indonesia tahun 2008 Nomor 94, tambahan Lembaran Negara Republik Indonesia Nomor 4867) tidak mempunyai kekuatan hukum mengikat. Dengan keluarnya putusan Mahkamah Konstitusi Nomor 93/ pUU-X/2012 maka sengketa ekonomi syariah secara litigasi menjadi kewenangan absolut peradilan agama.

Khusus di DKI Jakarta, penyelesaian sengketa secara litigasi dapat ditelusuri dari laporan perkara yang diterima dan diputus volume perkara sengketa ekonomi syariah yang diterima dan diselesaikan di peradilan agama wilayah PTA Jakarta adalah sebagai berikut: ${ }^{4}$

${ }^{4}$ Diolah dari laporan tentang perkara yang diterima dan diputus di seluruh wilayah Pengadilan Tinggi Agama Jakarta, diakses dari http:// pa-jakartaselatan.go.id tanggal 15 Oktober 2015.
Table 1

Daftar jumlah kasus ekonomi syariah di lingkungan PTA DKI Jakarta

\begin{tabular}{|c|c|c|c|c|c|c|}
\hline No & Satker & Tahun & $\begin{array}{c}\text { perkara } \\
\text { yang } \\
\text { diterima }\end{array}$ & $\begin{array}{l}\text { Perkara } \\
\text { yang } \\
\text { dicabut }\end{array}$ & $\begin{array}{c}\text { Perkara } \\
\text { yang } \\
\text { diputus }\end{array}$ & $\begin{array}{c}\text { Perkara } \\
\text { yang belum } \\
\text { diputus }\end{array}$ \\
\hline 1 & $\begin{array}{l}\text { PA } \\
\text { Jakarta } \\
\text { Selatan }\end{array}$ & $\begin{array}{l}2009- \\
2015\end{array}$ & 7 & 1 & 3 & 4 \\
\hline 2 & $\begin{array}{l}\text { PA } \\
\text { Jakarta } \\
\text { Timur }\end{array}$ & $\begin{array}{l}2009- \\
2015\end{array}$ & 0 & 0 & 0 & 0 \\
\hline 3 & $\begin{array}{l}\text { PA } \\
\text { Jakarta } \\
\text { Pusat }\end{array}$ & $\begin{array}{l}2009- \\
2015\end{array}$ & 5 & 1 & 3 & 1 \\
\hline 4 & $\begin{array}{l}\text { PA } \\
\text { Jakarta } \\
\text { Barat }\end{array}$ & $\begin{array}{l}2009- \\
2015\end{array}$ & 8 & 2 & 2 & 4 \\
\hline 5 & $\begin{array}{l}\text { PA } \\
\text { Jakarta } \\
\text { Utara }\end{array}$ & $\begin{array}{l}2009- \\
2015\end{array}$ & 2 & 0 & 2 & 0 \\
\hline
\end{tabular}

Berdasarkan data di atas ditemukan peradilan agama di wilayah PTA Jakarta yang belum pernah memutus perkara ekonomi syariah misalnya Pengadilan Agama Jakarta Timur. Namun, tepatnya dihari Senin, 12 Oktober 2015 Pengadilan Agama Jakarta Timur melaksanakan Sita Eksekusi dalam perkara Ekonomi Syariah untuk pertama kalinya semenjak berlakunya kewenangan pengadilan agama dalam menangani sengketa ekonomi syariah sebagaimana ditetapkan dalam Pasal 49 UU Nomor 3 Tahun 2006. Pelaksanaan eksekusi tersebut dilaksanakan berdasarkan Permohonan Eksekusi tertanggal 03 Juli 2015, dan telah terdaftar di Register Eksekusi Nomor 0001/Pdt.E/2015/PAJT dalam perkara antara PT. Bank Muammalat Indonesia sebagai "Pemohon Eksekusi" terhadap PT. Virgo Sari dengan putusan dimana kedua belah pihak dihukum untuk memenuhi isi dari Akta Perjanjian Pemberian Line Facility untuk Pembiayaan Mudharabah ${ }^{5}$.

Pengadilan Agama Jakarta Utara seperti disebut di atas telah memutus 2 perkara sengketa ekonomi syariah. Selain itu, Pengadilan Agama Jakarta Utara telah menerima surat Nomor W9-A1/866/HK.05/II/2015 mengenai permohonan bantuan pelaksanaan sita eksekusi hak tanggungan ${ }^{6}$ dan penjualan secara lelang.

\footnotetext{
${ }^{5}$ Pengadilan Agama Jakarta Timur Lakukan Sita Eksekusi Perkara Ekonomi Syariah, diakses dari http://www.pa-jakartatimur.go.id.

${ }^{6}$ Akad atau kontrak secara hukum perdata mengikat kedua belah pihak antara debitur dan kreditur. Apabila salah satu pihak melakukan wan prestasi atau inkar janji dari kontrak tersebut, maka sesuai akad dapat ditempuh eksekusi hak tanggungan. Sertifikat hak tanggungan mempunyai kekuatan eksekutorial yang sama dengan putusan pengadilan yang telah mempunyai hukum tetap, dan jika debitur cedera janji, maka berdasarkan titel eksekutorial yang terdapat dalam sertifikat hak tanggungan tersebut, pemegang hak tanggungan memohon eksekusi sertifikat hak tanggungan kepada ketua pengadilan
} 
Perkara ini terdaftar dengan Nomor 03/Eks/2014/PAJP ${ }^{7}$ tanggal 12 Pebruari 2015 dimana pemohon eksekusi adalah PT Bank Muamalat Indonesia.Tbk, beralamat di Gedung Arthaloka, jln Jenderal Sudirman Kav.2, Jakarta Pusat, termohon eksekusi, PT Tanjung Buton Makmur sejahtera, beralamat digedung Daya Mas, Jln Kisamaun no 169 Rt.03/06, Kelurahan Sukasari Tangerang. Objek yang ditanggungkan berupa sebuah kapal dengan nama lambung KM. Tanjung Buton Makmur sejahtera Tanda gelar GT, 5205No 286/ba. Saat ini bersandar disekitar pelabuhan Tanjung Periuk, Jakarta Utara ${ }^{8}$

Sedangkan penyelesaian sengketa dengan cara nonlitigasi dapat ditelusuri di Badan Arbitrase Syariah Nasional (BASYARNAS) yang berkedudukan di Jakarta. Mulai sejak berdirinya sampai 2015, volume perkara yang telah diselesaikan oleh BASYARNAS sejumlah 23 perkara dengan rincian; 1 perkara merupakan perkara perhotelan syari'ah, 1 perkara merupakan perkara asuransi syari ah sisanya (21 perkara) merupakan perkara tentang perbankan syri'ah dan 2 diantara 23 perkara tersebut sedang berjalan artinya belum diputuskan oleh arbiter atau majelis arbitrase pada saat wawanca dilakukan oleh peneliti. ${ }^{9}$

Melihat minimnya perkara yang diajukan ke pengadilan agama dan BASYARNAS sebagai entitas penyelesaian sengketa berbasis syariah memunculkan dugaan tentang pelaksanaan dan praktek bisnis syariah tidak rentan terhadap terjadinya sengketa atau sebaliknya tetapi ada cara lain yang digunakan dalam penyelesaian sengketa tersebut. Oleh karena itu, perlu melihat secara lansung ke masyarakat pelaku bisnis syariah khususnya lembaga-lembaga keuangan syariah seperti Bank Syariah, Asuransi Syariah dan koperasi syariah atau Baitul Mal Watamwil (BMT) tentang kecenderungan mereka untuk menyelesaikan sengketa ekonomi syariah.

\section{Teori Fiksi Hukum}

Teori ini dipelopori oleh sarjana Jerman Friedrich Carl von Savigny (1779-1861). Teori ini dianut di beberapa negara seperti Belanda dianut oleh Opzomer,

agama/mahkamah syariah yang berwenang. Lihat Mekkadilaga, Media Komunikasi Dan Konsultasi Administrator Peradilan Agama Edisi IV Tahun 2015, h.15.

${ }^{7}$ Permohonan eksekusi ditujukan ke PA Jakarta Pusat dalam hal ini PA Jakarta Pusat telah melakukan aanmaning sebanyak tiga kali, yaitu tanggal 30 Desember 2014 dan 20 januari 2015 dan 29 januari 2015. Pada saat aanmaning ketiga termohon membenarkan kewajiban atas sejumlah hutang yang harus dibayarkan dan kuasa pemohon menyatakan bahwa pelaksanaan eksekusi hak tanggungan (gross akta) dikembalikan kepada prosedur hukum sebagaimana permohonan pemohon eksekusi.

${ }^{8}$ Pengadilan Agama Jakarta Utara melakukan sita eksekusi hak tanggungan antara Bank Muamalat dengan PT Tanjung Buton makmur sejahtera dalam Mekkadilaga, Media komunikasi dan Konsultasi Administrator Peradilan Agama Edisi IV Tahun 2015, h.15.

${ }^{9}$ Wawancara dengan Euis Nurhasanah tanggal 3 Nopember 2015.
Diephuis, Land dan Houwing serta Langemeyer. Teori fiksi menjelaskan bahwa badan hukum hanya fiksi hukum dimana pengaturannya dilakukan oleh negara. Badan hukum itu hanya bayangan dan dianggap buatan negara saja. Sebenarnya badan hukum itu tidak ada, hanya orang menghidupkan bayangannya sebagai subjek hukum yang dapat melakukan perbuatan hukum seperti manusia. Fiksi hukum adalah asas yang menganggap semua orang tahu hukum (presumptio iures de iure). Dalam sebuah fiksi hukum, siapapun tanpa kecuali dianggap tahu hukum. Menjadi kesalahan besar jika seseorang tidak tahu hukum (ignorante legs est lata culpa). Dalam bahasa Latin dikenal pula adagium ignorantia jurist non excusat artinya ketidaktahuan hukum tidak bisa dimaafkan. Seseorang tidak bisa menghindar dari jeratan hukum dengan berdalih belum atau tidak mengetahui adanya hukum dan peraturan perundang-undangan tertentu.

Ketidaktahuan masyarakat atas undang-undang tidak dapat dimaafkan (ignorantia jurist non excusat). Fiksi hukum bisa dibilang merupakan asas yang mengandung alasan pembenar dari negara buat memaksakan segala sesuatu kepada rakyatnya. Adagium fiksi hukum sudah lama ditinggalkan, tetapi faktanya pandangan ini dianut dunia peradilan, baik Mahkamah Agung (MA) maupun Mahkamah Konstitusi (MK). Putusan MA No. 645K/Sip/1970 dan putusan MK No. 001/PUU-V/2007 memuat prinsip yang sama yaitu ketidaktahuan seseorang akan undang-undang tidak dapat dijadikan alasan pemaaf. Putusan MA No. 77 K/ $\mathrm{Kr} / 1961$ menegaskan bahwa tiap-tiap orang dianggap mengetahui undang-undang setelah undang-undang itu diundangkan dalam lembaran negara

\section{Teori Sistem Hukum}

Sistem hukum merupakan satu kesatuan yang terdiri atas unsur-unsur atau elemen yang saling berinteraksi satu sama lain. Sistem hukum ada yang terbuka dan tertutup. Sistem hukum terbuka maksudnya unsurunsur dari sistem itu mempengaruhi unsur-unsur di luar sistem. Sedangkan yang dimaksud sistem hukum tertutup adalah unsur-unsur sistem hukum yang tidak dapat dipengaruhi oleh unsur di luar sistem.

Sistem hukum yang baik dapat dilihat dari tata cara kerja dan tata kelola semua unsur untuk menegakkan hukum dalam rangka menciptakan kepastian hukum. Masing-masing unsur saling mempengaruhi dan saling menguatkan dalam menjalankan fungsi-fungsinya. Fungsi sistem hukum yang dimaksud adalah (1) Sebagai bagian dari sistem kontrol sosial (social control) yang mengatur perilaku manusia; (2) Sarana untuk menyelesaikan sengketa (dispute settlement); (3) Sebagai social engineering 
function; (4) Social maintenance yaitu fungsi yang menekankan peranan hukum sebagai pemeliharaan status quo yang tidak menginginkan perubahan

Sistem hukum suatu negara sangat mempengaruhi efektifitas penegakan hukum. Ada 3 unsur sistem hukum sebagaimana dijelaskan Lawrence M. Friedman yaitu: Struktur Hukum (Structure of law), Substansi hukum (Substance of law) dan budaya hukum (legal culture $^{10}$. Struktur Hukum merupakan kelembagaan yang diciptakan sistem hukum yang berwenang membuat dan melaksanakan hukum dalam bentuk pelayanan dan penegakan hukum. Jadi, struktur hukum menyangkut aparat pembuat hukum seperti lembaga legislatif dan penegak hukum seperti pengadilan. Substansi hukum merupakan norma-norma hukum (peraturan dan keputusan) yang dihasilkan dari produk hukum. Jadi substansi hukum meliputi perangkat peraturan perundang-undangan. Sedangkan budaya merupakan sikap orang terhadap hukum dan sistem hukum itu sendiri yang meliputi kepercayaan akan nilainilai, pikiran-pikiran atau ide-ide, sikap, harapan, dan pendapat yang berhubungan dengan hukum baik positif maupun negatif. Jadi budaya hukum merupakan hukum yang hidup (living law) yang dianut dalam masyarakat.

Struktur hukum yang baik tidak akan berjalan dengan baik kalau tidak ditunjang oleh substansi hukum yang baik. Demikian pula substansi hukum yang baik tidak akan dapat dirasakan manfaatnya kalau tidak ditunjang oleh Struktur hukum yang baik. Selanjutnya struktur dan substansi hukum yang baik tidak akan dapat dirasakan eksistensinya kalau tidak didukung oleh budaya hukum masyarakat yang baik pula. Struktur dan substansi hukum merupakan komponenkomponen riil dari sistem hukum. Tetapi keduanya hanya merupakan cetak biru atau rancangan dan bukan mesin yang tengah bekerja. Kedua komponen ini seperti foto diam yang tidak bernyawa, kaku, beku dan tidak menampilkan gerak dan kenyataan.

Sistem hukum akan bekerja jika terdapat kekuatankekuatan sosial (social force) yang menggerakkan hukum. Kekuatan-kekuatan itu terdiri atas elemen nilai dan sikap sosial yang dinamakan dengan budaya hukum (legal culture). Social force merupakan sebuah abstraksi yang tidak secara lansung menggerakkan sistem hukum tetapi perlu diubah menjadi tuntutan-tuntutan formal untuk menggerakkan bekerjanya sistem hukum di pengadilan.

Fiedmen menelaah budaya hukum nasional berbeda dengan subbudaya hukum yang berpengaruh secara positif atau negatif terhadap hukum nasional. Ia juga

\footnotetext{
${ }^{10}$ Lawrence M. Frietman, American Law, (Ner York: WW. Norton \& company, 1984), h. 5-6.
}

membedakan budaya hukum internal dan eksternal. Budaya hukum internal merupakan budaya hukum dari warga masyarakat yang melaksanakan tugas-tugas hukum seperti polisi, jaksa dan hakim dalam menjalankan tugasnya. Sedangkan budaya hukum eksternal merupakan budaya hukum masyarakat pada umumnya. Misalnya bagaimana sikap dan pengetahuan masyarakat terhadap ketentuan perpajakan, perceraian dan lain sebagainya.

Hukum merupakan subsistem dalam sistem kehidupan bernegara. Sebagai salah satu sistem, hukum akan mempengaruhi kinerja-kinerja sistem-sistem lain dalam kehidupan bernegara. Negara yang sistem hukumnya demokratis akan menciptakan kehidupan demikratis dalam segala bidang kehidupan. Demokratisasi hukum ditentukan oleh strategi pembangunan hukum yang dianut oleh suatu Negara. ${ }^{11}$

\section{Preferensi Masyarakat Ekonomi Syariah dalam Memilih Lembaga Penyelesaian Sengketa}

Kecenderungan Lembaga Keuangan Syariah untuk memilih lembaga penyelesaian sengketa ekonomi syariah dapat dilihat pada tabel berikut:

Tabel 2

Daftar pilihan penyelesaian sengketa ekonomi syariah responden

\begin{tabular}{clcc}
\hline No & \multicolumn{1}{c}{ Lembaga } & $\begin{array}{c}\text { Angka pada Table } \\
\text { Frequensi }\end{array}$ & $\begin{array}{c}\text { Prosentase } \\
(\%)\end{array}$ \\
\hline 1 & Pengadilan Agama & 72,7 & $41,6 \%$ \\
\hline 2 & Pengadilan Negeri & 11,4 & $6,5 \%$ \\
\hline 3 & BASYARNAS & 25 & $14,3 \%$ \\
\hline 4 & $\begin{array}{l}\text { Lembaga ADR } \\
\text { lainnya }\end{array}$ & 23,8 & $13,6 \%$ \\
\hline 5 & Informal & 41,9 & $24 \%$ \\
\hline
\end{tabular}

Dalam rangka penyelesaian sengketa ekonomi syariah, pengadilan agama merupakan pilihan tertinggi para responden yaitu sebesar 41,6\%. Berikutnya disusul dengan cara penyelesaian sengketa secara informal yaitu sebesar $24 \%$, BASYARNAS sebesar 14,3\%, lembaga ADR lainnya sebesar 13,6 \% dan pengadilan negeri sebesar $6,5 \%$. Hal yang menarik dari paparan ini adalah besarnya porsi penyelesaian sengketa ekonomi syariah secara informal yaitu $24 \%$. Penyelesaian sengketa secara informal peringkat kedua setelah pengadilan agama. Setelah dilakukan telaah ulang untuk melihat secara pasti besaran kecenderungan lembaga keuangan syariah untuk memilih lembaga penyelesaian sengketa ekonomi

${ }^{11}$ Josept Raz, The Concept of A Legal System, (New York: Clarandom Press Oxford, 1980), h. 112-113 dalam buku Teguh Prastyo dan Abdul Halim Barkatullah, Filsafat, Teori dan Ilmu Hukum: Pemikiran Menuju Masyarakat Berkeadilan dan Bermartabat, (Jakarta: PT. RajaGrafindo Persada, 2013), Cet. Ke-2, h. 314. 
syariah, Baitul Mal Wattamwil (BMT) merupakan institusi terbesar yang menggunakan penyelesaian secara informal. Ini terlihat pada table berikut:

Tabel 3

Pilihan penyelesaian sengketa ekonomi syariah oleh BMT

\begin{tabular}{clcc}
\hline No & \multicolumn{1}{c}{ Lembaga } & $\begin{array}{c}\text { Angka pada } \\
\text { table Frequency }\end{array}$ & $\begin{array}{c}\text { Prosentase } \\
(\%)\end{array}$ \\
\hline 1 & Pengadilan Agama & 47,7 & $20,56 \%$ \\
\hline 2 & Pengadilan Negeri & 26,3 & $11,34 \%$ \\
\hline 3 & BASYARNAS & 47,4 & $20,43 \%$ \\
\hline 4 & Lembaga ADR lainnya & 47,4 & $20,43 \%$ \\
\hline 5 & Informal & 63,2 & $27,24 \%$ \\
\hline
\end{tabular}

Berdasarkan data terlihat bahwa kecenderungan BMT memilih lembaga dan cara penyelesaian sengketa cukup beragam. Meskipun keberagaman pilihan BMT didominasi dengan cara informal yaitu sebesar 27,24\%. Namun dalam kenyatannya, BMT sebagai lembaga keuangan mikro syariah belum sampai pada tahap penyelesaian sengketa ke tahap litigasi dan non-litigasi seperti bank syariah dan asuransi Syariah. Selain platfon dan kemampuan memberikan pembiayaan bersifat mikro, penggunaan dana pembiayaan pun sulit untuk dipantau. Oleh karena itu, BMT lebih memilih cara penyelesaian sengketa ekonomi syariahnya dengan cara informal.

\section{Faktor-Faktor yang Mempengaruhi Lembaga Keuangan Syariah untuk Memilih Lembaga Penyelesaian Sengketa Ekonomi Syariah}

Pilihan lembaga keuangan syariah untuk memilih lembaga dan cara penyelesaian sengketa ekonomi syariah sangat beragam. Keberagaman pilihan tersebut yaitu: Pertama, faktor regulasi. Dengan beragamnya aturan perundang-undangan yang mengatur lembaga penyelesaian sengketa maka beragam pula pilihan masyarakat untuk memilih lembaga penyelesaian sengketa ekonomi syariah meskipun Keputusan Mahkamah Konstitusi No. 93/ PUU-X/2012 atas pembatalan penjelasan ayat 2 pasal 55 UU No. 21 Tahun 2008 telah memperkuat kompetensi absolut pengadilan agama dalam hal penyelesaian sengketa ekonomi syariah.

BTN Syariah sebelum keluar fatwa DSN No. 83/DSNMUI/VI/2012 tentang Penjualan Langsung Berjenjang Syariah Jasa Perjalanan Umrah, memilih BASYARNAS untuk penyelesaian sengketa ekonomi syariah. Hal ini sesuai dengan fatwa DSN No. 80/DSN-MUI/III/2011 tentang Penerapan Prinsip Syariah dalam Mekanisme Perdagangan Efek Bersifat Ekuitas di Pasar Reguler Bursa Efek yang jelas menyatakan penyelesaian sengketanya melalui BASYARNAS. Setelah keluar fatwa DSN
No. 83/DSN-MUI/VI/2012, penyelesaian sengketanya melalui pengadilan agama. Dalam Prakteknya, terkadang penyelesaian sengketa dilakukan melalui pengadilan negeri. Hal itu disebabkan oleh adanya kemauan penggugat yang masih meyakini dan mempercayai pengadilan negeri. Ketika penggugat dalam hal ini nasabah bank baik dalam bentuk perseorangan maupun lembaga mengajukan penyelesaian sengketa ekonomi syariah ke pengadilan negeri maka bank syariah sebagai tergugat ada dua kemungkinan, yaitu mengajukan esepsi berdasarkan kesepakatan di klausul kontrak bahwa penyelesaian sengketa di pengadilan agama dan memenuhi kemauan pihak penggugat karena menurut analisa pihak tergugat tidak terlalu memberatkan tergugat. ${ }^{12}$

Hal yang sama juga terjadi di Bank Syariah Mandiri (BSM). Terkadang penyelesaian sengketa dilakukan melalui BASYARNAS dengan pelaksana eksekusi putusan BASYARNAS ada yang melalui pengadilan agama dan ada yang melalui pengadilan negeri. ${ }^{13}$ Sementara Bank Muamalat Indonesia (BMI) menyelesaikan sengketa ekonomi Syariah sebelum keluarnya UU No. 3 Tahun 2006 melalui BASYARNAS. Setelah diterapkan UU No. 3 Tahun 2006 ini bahkan sebelum adanya Keputusan Mahkamah Konstitusi dalam putusan No. 93/ PUU-X/2012 atas pembatalan penjelasan ayat 2 pasal 55 UU No. 21 Tahun 2008 tentang Perbankan Syariah maka penyelesaian sengketa ekonomi syariah Bank Muamalat Indonesia melalui pengadilan agama.

Khusus dalam kontrak yang sifatnya tidak dalam bentuk kontrak produk perbankan dalam kegiatan operasional perbankan yang menjalankan fungsi intermediasi seperti kontrak pengadaan barang, renovasi dan pembangunan, jika terjadi sengketa maka penyelesaiannya adalah BASYARNAS karena kontrak seperti ini termasuk dalam kontrak perdata umum. ${ }^{14}$ Di lembaga perasuransian syariah pun tidak jauh berbeda dengan praktek yang terjadi di perbankan syariah dalam hal penyelesaian sengketa ekonomi syariah. Penyelesaian sengketa di PT. Takaful Indonesia dan PT. Takaful Keluarga adalah melalui BASYARNAS dan pengadilan agama. Sedangkan perusahaan asuransi syariah lainnya, selain penyelesaian sengketanya melalui BASYARNAS dan pengadilan agama, masih ada melalui pengadilan negeri. ${ }^{15}$

Setelah memperhatikan praktek-praktek penyelesaian sengketa ekonomi syariah di lembaga keuangan syariah,

${ }^{12}$ Hasil wawancara dengan salah seorang legal officer bank BTN pada tanggal 28 Oktober 2015.

${ }^{13}$ Berdasarkan beberapa contoh kontrak yang ada di BSM.

${ }^{14}$ Berdasarkan hasil wawancara peneliti dengan salah seorang legal officer Bank Muamalat Indonesia pada tanggal 20 Oktober 2015.

15 Berdasarkan beberapa contoh kontrak di beberapa lembaga asuransi syariah. 
peneliti memahami bahwa ada dua faksi praktek penyelesaian sengketa ekonomi Syariah, yaitu faksi lembaga keuangan syariah baik bank maupun asuransi syariah yang sepenuhnya tunduk pada UU No. 3 Tahun 2006 dan faksi lembaga keuangan syariah baik bank maupun asuransi syariah yang tidak sepenuhnya tunduk pada UU No. 3 Tahun 2006 karena masih ada yang memilih pengadilan negeri untuk memeriksa perkara ekonomi syariah.

Kedua faksi ini muncul disebabkan adanya value, keyakinan, cara pandang dan tradisi yang tumbuh dan hidup di lingkungan setiap lembaga keuangan syariah. Bank Syariah Mandiri, misalnya, yang kental dan sarat dengan value yang dianut dan tradisi yang berlaku di Bank Mandiri khususnya dalam hal penyelesaian sengketa yang sudah terbiasa menggunakan pengadilan negeri. Begitu juga dengan BTN Syariah sebagai Unit Usaha Syariah (UUS) dari Bank Tabungan Negara (BTN) yang juga sudah menjadi tradisi dalam hal penyelesaian sengketa melalui pengadilan negeri. Berbeda dengan Bank Muamalat Indonesia, PT. Takaful Indonesia dan Takaful Keluarga yang dari awal berdirinya memiliki muatan tradisi kesyariahan yang cukup kental. Dalam kajian hukum, value, keyakinan, cara pandang dan tradisi seperti ini lebih dikenal dengan istilah budaya hukum sebagaimana dalam teori sistem hukum Friedmen.

Kedua, faktor asas kebebasan dalam berkontrak. Beragamnya klausul penyelesaian sengketa pada lembagalembaga keuangan syariah dimungkinkan karena adanya asas kebebasan berkontrak ${ }^{16}$ (party autonomy atau freedom of contract) sebagaimana diatur dalam pasal 1338 ayat (1) KUH Perdata yang menyebutkan bahwa semua perjanjian yang dibuat secara sah berlaku sebagai undang-undang bagi mereka yang membuatnya. Sebagai konsekuensi logis dari diberlakukannya prinsip kebebasan berkontrak (freedom of contract) maka, para pihak dalam suatu kontrak dapat menentukan: (1) Pilihan hukum (choice of law) dimana para pihak menentukan sendiri dalam kontrak tentang hukum mana yang berlaku terhadap interpretasi kontrak tersebut. (2) Pilihan forum (choice of forum atau choice of jurisdiction) yaitu para pihak menentukan sendiri dalam kontrak tentang pengadilan atau forum mana yang berlaku jika terjadi sengketa di antara para pihak dalam kontrak tersebut. (3) Pilihan domisili (choice of domicilie) yaitu masing-masing pihak melakukan penunjukan dimana domisili hukum dari para pihak tersebut. ${ }^{17}$

${ }^{16}$ Asas kebebasan berkontrak adalah suatu asas yang memberikan kebebasan kepada para pihak untuk membuat atau tidak membuat perjanjian, mengadakan perjanjian dengan siapapun, menentukan isi perjanjian, pelaksanaan, dan persyaratannya dan menentukan bentuk perjanjian baik tulisan maupun lisan. Salim, Hukum Kontrak: Teori dan Teknik Penyusunan Kontrak, (Jakarta: Sinar Grafika, 2006), Cet. Ke-4, h. 9.

${ }^{17}$ Munir Fuady, Hukum Kontrak: Dari Sudut Pandang Hukum
Menurut peneliti, kepastian hukum yang dicitacitakan oleh Keputusan MK untuk mempertegas kompetensi absolut pengadilan agama dalam hal menyelesaikan sengketa ekonomi syariah masih belum terwujud dengan seutuhnya karena masih ada para pihak yang bersengketa mengajukan penyelesaian sengketa ke pengadilan negeri dengan dalih adanya asas kebebasan berkontrak yang dianut. Sudargo Gautama menyebutkan bahwa pilihan hukum dan pilihan forum dalam konteks kebebasan berkontrak tidak boleh dilaksanakan secara serampangan. Pilihan hukum dan pilihan forum yang dimaksud tidak boleh menyalahi dan bertentangan dengan aturan perundang-undangan yang berlaku. ${ }^{18}$

Kebebasan berkontrak pada ayat 2 pasal 55 UU No. 21 Tahun 2008 tentang perbankan syariah ini pasca Keputusan Mahkamah Konstitusi dalam putusan No. 93/PUU-X/2012 hanya memungkinkan pilihan para pihak memilih pengadilan agama untuk menyelesaikan sengketa ekonomi syariah dengan cara litigasi atau lembaga ADR (alternative despiute Resolution) seperti BASYARNAS sebagaimana yang diatur dalam UU No. 30 Tahun 1999 tentang arbitrase.

Ketiga, faktor sumber daya manusia. Sumber daya manusia lazimnya disebut dengan sumber daya insani dalam kontek ekonomi syariah. Dalam hal ini para legal yang ada dipelbagai lembaga keuangan syariah sangat beragam latar belakangnya mulai dari sarjana hukum umum, hukum Islam yang dalam hal ini muamalat (hukum ekonomi dan bisnis syariah) dan sarjana syariah. Berdasarkan hasil wawancara dengan salah seorang legal bank syariah dijelaskan bahwa mayoritas para legal berlatal belakang hukum umum. Upaya yang dilakukan sekarang adalah dengan meningkatkan kompetensi para legal dalam hal hukum Islam dan ilmu kesyariahan dengan cara pelatihan dan sertifikasi. Selain itu pola rekruitmen para legal officer sudah terbuka untuk menerima para sarjana yang mempunyai latar belakang hukum Islam dalam hal ini muamalat (hukum ekonomi dan bisnis syariah) dan sarjana syariah.

Berdasarkan hasil wawancara peneliti dengan salah seorang nara sumber BTN Syariah terkait dengan kontrak, tidak semua kontrak-kontak bisnis lembaga keuangan dibuat oleh para legal officer. Data-data otentik yang dibutuhkan dalam kontrak bisnis seperti pembiayaan komersil misalnya, membutuhkan jasa para notaris terutama pada pembiayaan yang bersifat komersil sebagaimana yang terdapat di BTN Syariah. Para notaris di Indonesia, mayoritas kompetensinya di bidang hukum

Bisnis, (Bandung: PT. Citra Aditya Bakti, 2003), Buku ke-2, Cet. Ke1, h. 137.

18 Sudargo Gautama, Hukum Perdata Internasional Indonesia, (Jakarta: Bina Cipta, 1992), Jilid III, bagian 2, buku ke-8, h. 170. 
ekonomi dan bisnis syariah serta ilmu kesyariahan juga belum maksimal. Selain itu, bentuk kontrak dan akta syariah juga belum ada yang baku sesuai regulasi sebagaimana kontrak dan akta umum. Kondisi inilah yang menyebabkan penalaran para legal beragam dalam memahami kebebasan dalam berkontrak. Penalaran mereka berpengaruh terhadap pilihan hukum dalam hal penyelesaian sengketa ekonomi syariah sebagaimana pada poin 2. Seyogyanya Mahkamah Agung mengeluarkan surat edaran ke pengadilan negeri untuk tidak menerima penyelesaian sengketa ekonomi syariah dalam rangka menjamin kepastian hukum atas kompetensi obsolut pengadilan agama.

Keempat, faktor kelembagaan. Kelembagaan yang dimaksud di sini adalah kompetensi lembaga yaitu pengadilan agama, pengadilan negeri dan BASYARNAS serta kompetensi para hakim dan para arbiter. Adapun Respon responden terhadap 3 lembaga penyelesaian sengketa dapat dilihat pada tabel berikut:

Tabel 4

Pilihan responden berdasarkan kompetensi lembaga

\begin{tabular}{clcc}
\hline No & \multicolumn{1}{c}{ Lembaga } & $\begin{array}{c}\text { Angka Table } \\
\text { Frequency }\end{array}$ & $\begin{array}{c}\text { Prosentase } \\
(\%)\end{array}$ \\
\hline 1 & $\begin{array}{l}\text { Pengadilan } \\
\text { Agama }\end{array}$ & 72,7 & $54,25 \%$ \\
\hline 2 & $\begin{array}{l}\text { Pengadilan } \\
\text { Negeri }\end{array}$ & 22,7 & $16,94 \%$ \\
\hline 3 & BASYARNAS & 38,6 & $28,81 \%$ \\
\hline
\end{tabular}

Sementara respon responden terhadap kompetensi para hakim pengadilan agama dan pengadilan negeri serta arbiter BASYARNAS dalam menyelesaikan sengketa ekonomi syariah dapat dilihat pada table berikut:

Tabel 5

Pilihan responden berdasarkan kompetensi para hakim dan arbiter

\begin{tabular}{clcc}
\hline No & \multicolumn{1}{c}{ Lembaga } & $\begin{array}{c}\text { Angka Table } \\
\text { Frequency }\end{array}$ & $\begin{array}{c}\text { Prosentase } \\
(\%)\end{array}$ \\
\hline 1 & $\begin{array}{l}\text { Hakim Pengadilan } \\
\text { Agama }\end{array}$ & 65,9 & $53,23 \%$ \\
\hline 2 & $\begin{array}{l}\text { Hakim Pengadilan } \\
\text { Negeri }\end{array}$ & 13,7 & $11,07 \%$ \\
\hline 3 & $\begin{array}{l}\text { Arbiter } \\
\text { BASYARNAS }\end{array}$ & 44,2 & $35,7 \%$ \\
\hline
\end{tabular}

Apa yang ditunjukkan berdasarkan data ini sesuai dengan ungkapan Rifyal Ka'bah tahun 2010 yang menjelaskan bahwa hakim agama cukup memadai dalam memutus perkara ekonomi syariah. Hal ini dapat dilihat dari sudah adanya belasan perkara ekonomi syariah yang masuk ke pengadilan agama tetap bisa diselesaikan dengan baik hingga sampai usaha kasasi. Persoalan sedikitnya kasus yang masuk, tergantung pada kemauan pihak sesuai kontrak untuk penyelesaian sengketa melalui pengadilan agama atau BASYARNAS.

Kelima, faktor efisiensi waktu dan biaya. Respon responden terhadap efisiensi waktu berperkara di lembaga litigasi dan non-litigasi dapat dilihat pada tabel berikut:

\begin{tabular}{clcc}
\hline No & \multicolumn{1}{c}{ Lembaga } & $\begin{array}{c}\text { Angka Table } \\
\text { Frequency }\end{array}$ & $\begin{array}{c}\text { Prosentase } \\
(\%)\end{array}$ \\
\hline 1 & Pengadilan Agama & 15,6 & $18,33 \%$ \\
\hline 2 & Pengadilan Negeri & 42,2 & $49,6 \%$ \\
\hline 3 & BASYARNAS & 27,3 & $32,07 \%$ \\
\hline
\end{tabular}

Sedangkan respon responden terhadap efisiensi biaya berperkara di lembaga litigasi dan non-litigasi dapat dilihat pada tabel berikut:

\begin{tabular}{cccc}
\hline No & Lembaga & Prosentase (\%) & Keterangan \\
\hline 1 & Pengadilan Agama & 17,7 & $24,5 \%$ \\
\hline 2 & Pengadilan Negeri & 34 & $48,5 \%$ \\
\hline 3 & BASYARNAS & 20,5 & $28,4 \%$ \\
\hline
\end{tabular}

Berdasarkan prosentase yang dipaparkan pada tabel-tabel frekuensi yang lalu menunjukkan bahwa efisiensi waktu dan biaya berperkara tidak dominan dibandingkan faktor-faktor yang lain. Analisa peneliti senada dengan pendapat Mirza Karim, seorang lawyer di Karim Consulting, yang menjelaskan bahwa lama dan singkatnya waktu yang dibutuhkan untuk berperkara dan murah-mahalnya biaya berperkara melalui pengadilan dan BASYARNAS bersifat relatif dari segi waktu sudah jelas. Pengadilan lebih lama bila dibandingkan dengan BASYARNAS dan lembaga ADR lainnya karena jika perkara dilanjut ke banding dan kasasi. Bisa juga suatu waktu singkat jika putusan pengadilan tingkat pertama dapat diterima. Mahal dan murahnya biaya berperkara juga bersifat relatif. Berperkara di pengadilan bisa jadi lebih murah kalau putusan pengadilan tingkat pertama dapat diterima. Namun mesti diingat juga bahwa putusan pengadilan dapat dibanding ke pengadilan tinggi dan selanjutnya juga dapat kasasi ke MA dan juga memungkinkan untuk minta peninjauan kembali ke MA. Semakin lama prosesnya semakin banyak dan mahal biayanya apalagi jika menggunakan jasa advokat. Biaya berperkara melalui arbitrase memungkinkan juga lebih mahal karena secara kelembagaan seperti BASYARNAS bukan badan milik pemerintah. Namun putusannya tidak dapat dibanding apalagi kasasi. Selain itu jika pihak kalah beriktikad tidak baik dalam arti putusan arbitrase tidak secara suka rela dipatuhi sehingga meminta penetapan eksekusi ke pengadilan negeri.

Berkaitan dengan efisiensi waktu dan biaya berperkara, secara khusus BMT sebagai lembaga keuangan mikro syariah belum sampai pada tahap penyelesaian sengketa seperti lembaga keuangan syariah lainnya 
seperti bank dan asuransi syariah. Selain platform dan kemampuan memberikan pembiayaan bersifat mikro, penggunaan dana pembiayaan pun sulit untuk dipantau. Oleh karena itu, BMT lebih memilih cara penyelesaian sengketa ekonomi syariahnya dengan cara informal.

\section{Penutup}

Lembaga keuangan syariah sangat beragam untuk memilih cara dan memilih lembaga penyelesaian sengketa ekonomi Syariah. Ada yang memilih pengadilan agama, BASYARNAS, lembaga ADR lainnya bahkan pengadilan negeri. Beragamnya pilihan responden untuk memilih lembaga penyelesaian sengketa atas pengadilan agama, BASYARNAS dan lembaga ADR lainnya serta pengadilan agama disebabkan oleh 5 faktor yaitu faktor regulasi, asas kebebasan berkontrak, sumber daya manusia, kelembagaan dan efisiensi waktu serta biaya berperkara.

Dengan beragamnya penafsiran para ahli hukum dan legal officer serta praktisi hukum lainnya untuk menterjemahkan UU No. 3 Tahun 2006 yang mempertegas kompetensi absolut peradilan agama dalam hal ekonomi syariah dan UU No. 21 Tahun 2008 tentang Perbankan Syariah meskipun penjelasan ayat 2 Pasal 55 UU No. 21 Tahun 2008 tentang Perbankan syariah sudah dibatalkan oleh Mahkamah Konstitusi dengan keputusan No. 93/ PUU-X/2012 sehingga masih ditemukan penyelesaian sengketa ekonomi syariah diselesaikan melalui pengadilan negeri bahkan eksekusi BASYARNAS pun masih ada yang dilakukan oleh pengadilan negeri. Seyogyanya Mahkamah Agung secara tegas melalui surat edaran ke pengadilan negeri untuk tidak menerima penyelesaian sengketa terkait dengan bisnis dan ekonomi syariah.

Karena persoalan juga menjadi problem utama dalam penyelesaian sengketa ekonomi syariah. Oleh karena itu perlu upaya untuk meningkatkan kompetensi sumber daya manusia. Selain itu, rekruitmen calon sumber daya manusia di bidang hukum ekonomi dan bisnis syariah baik yang didistribusikan sebagai akademisi maupun praktisi hukum juga diperlukan. Seyogyanya pemerintah mendukung dan menggalakkan lembagalembaga pendidikan formal yang konsen kepada kajian dan program studi hukum ekonomi dan bisnis syariah serta memberikan regulasi yang jelas untuk merekruit para lulusan hukum ekonomi bisnis syariah tersebut.[]

\section{Pustaka Acuan}

Azhar, Cholidul, Aspek Hukum Bank Syariah dalam Kaitannya dengan KompetensiAbsolut Pengadilan Agama, diakses dari www. badilag. net.

Bisri, Cik Hasan, Peradilan Agama Di Indonesia, Jakarta: Raja Grapindo Persada, 1996.
Diklat Calon Hakim Angkatan-2 di Banten, 2007.

Djamil, Faturrahman, Penyelesaian Pembiayaan Bermasalah di Bank Syariah, Jakarta: Sinar Grafika, cet 2,2014

Djauhari, Ahmad, Arbitrase Syariah di Indonesia, Jakarta: BASYARNAS, 2006.

Frietman, Lawrence M., American Law, New York: WW. Norton \& company, 1984.

Gautama, Sudargo, Hukum Perdata Internasional Indonesia, Jakarta: Bina Cipta, 1992, Jilid III, bagian 2, buku ke-8.

Goodpaster, Garry, "Tinjauan terhadap Penyelesaian Sengketa", dalam Agnes Toar dkk, Dasar Hukum Ekonomi 2 Abitrase Indonesia, Jakarta: Gralia Indonesia, 1995.

Hasbi, Kompetensi Peradilan Agama dalam Perkara Ekonomi Syariah, Disertasi Sekolah Pascasarjana Universitas Islam negeri Syarif Hidayatullah Jakarta tahun 2009.

Kardono, A.Suiani, Hukum dan Lembaga Arbitrase di Indonesia, Jakarta: t.p, tt.

Manan, Abdul, Beberapa Masalah Hukum dalam Praktek ekonomi Syariah, Makalah

Mekkadilaga, Media Komunikasi dan Konsultasi Administrator Peradilan Agama Edisi IV Tahun 2015.

Mujahidin, Ahmad, Prosedur Penyelesaian Sengketa Ekonomi Syariah di Indonesia, Bogor: Ghalia, Indonesia, 2010.

Prastyo, Teguh dan Abdul Halim Barkatullah, Filsafat, Teori dan Ilmu Hukum: Pemikiran Menuju Masyarakat Berkeadilan dan Bermartabat, Jakarta: PT. RajaGrafindo Persada, 2013, Cet. Ke-2.

Rahmi, Diana, Ruang Lingkup Kewenangan Peradilan Agama Dalam Mengadili Sengketa Ekonomi Syariah, diakses dari syariah.iain-antasari.ac.id.

Rasyid, Roihan A., Hukum Acara Peradilan Agama, Jakarta : PT. Raja Grafindo Persada, 2002.

Ritonga, A.Rahman, et.al, Ensiklopedi Hukum Islam, cet. 4, Jakarta: PT. Ichtiar Baru van Hoeve, 2000.

Rosyadi, Rahmat dan Ngatino, Arbitrase dalam Perspektif Islam dan Hukum Positif, Bandung: PT. Citra Aditya Bakti, 2001.

Sumitro, Warkum, Asas-asas Perbankan Islam dan Lembaga-lembaga Terkait, Jakarta: PT Radjagrafindo, 2002.

Umam, Khotibul, Kembalinya Kompetensi Absolut Peradilan Agama, dalam Majalah Konstitusi, Edisi September, 2013 No 79

Umam, Khotibul, Penyelesaian Sengketa di Luar Pengadilan, Yogyakarta: Pustaka Yustisia, 2010.

Usman, Rahmadi, Pilihan Penyelesaian Sengketa di Luar Pengadilan, Bandung: PT. Citra Aditya Bakti,2003. 